\title{
Interrogating Infanticide/ Child Euthanasia in the Roman Christian Era, Vis-⿳亠丷⿵-Vis the Abuja Practice
}

\author{
Monica Omoye Aneni* \\ http://dx.doi.org/10.4314/ujah.v14i2.2
}

\section{Abstract}

The purpose of this paper is an attempt to examine infanticide practices in the Roman Christian era and interrogate infanticide and child euthanasia in the same era. It also attempts to point out infanticide practices in Abuja and makes a distinction between infanticide and child euthanasia in Abuja. The study employed historical and comparative methodologies to highlight the issues surrounding infanticide/child euthanasia in the Roman Christian era and infanticide in Abuja. A deliberate attempt at population reduction and man's instinctive nature towards his survival are some of the rationales for the practice of infanticide in antiquity and Abuja. The paper concludes with the argument that infanticide and child euthanasia are one and the same in antiquity, and infanticide in Abuja continues to be practiced due to lack of education and enlightenment of the people who performed them. Further studies could examine diverse religious inclinations toward infanticide/ or child euthanasia in the Graeco-Roman world and the modern world.

Keywords: infanticide, child euthanasia, Roman Christian era, Abuja,

\section{Introduction}

Infanticide in antiquity has elicited debates in the scholarly arena. Various classical as well as modern authors have documented incidences of infanticide in antiquity as well as 
the Hellenistic world. While some modern authors argued that female infanticide was common and had considerable effect on the demography of the Greaco-Roman world, others have postulated that infanticide was a deliberate attempt at population reduction. Some others have also argued that it occurred because of man's instinctive nature towards his survival. Yet, these authors, while discussing infanticide, have not altogether fully focused on infanticide in the Roman Christian era, in Abuja as well as attempt to interrogate child euthanasia. This paper, while discussing the issues, will draw on the works of classical and modern authors as well as first hand experiences of infanticide practices in Abuja, Nigeria.

\section{Methodology}

The study employed historical and comparative methodologies to highlight the issues surrounding infanticide in the Roman Christian era, and Abuja. It also discusses the similarities between infanticide and child euthanasia. Sources utilized were works of classical and modern authors. Information was also gathered from medical literature and newspaper reports. The data were subjected to content analysis.

\section{Infanticide}

Infanticide and child euthanasia because of semantics have different definitions. However, they are the same in meaning and practice. It is important that for the purpose of this paper, definitions of infanticide and child euthanasia be made as it would aid further discussions on the subject.

Infanticide is the willful killing of an infant child through exposure and abandonment of an infant child. It is the "homicide of a person older than one week, but less than one year of age." (Moran D. R http://www.deathreference.com/HoKa/Infanticide.html). The Columbia Encyclopedia defines infanticide as "the putting to death of the newborn with the 
consent of the parents, family or community"(Columbia Encyclopaedia, 2008). The wikipedia also defines infanticide as "the practice of someone intentionally causing the death of an infant and often, it is the mother who commits the act" (http://en.wikipedia.org/wiki/Infanticide). The definitions from the first two can be acceptable. However one may disagree with the view of that of the wikipeidia. That ". . .the mother. . . commits the crime", is an assumption, for there is no evidence or result of experiential study that may support the claim. Boswell (1984) defines infanticide as the “... voluntary and permanent relinquishing of control over children by natal parents or guardians, whether by leaving them somewhere, selling them, or legally consigning care and control to some other person." Boswell's definition suggests that this was the period when the practice of infanticide was being questioned by people Also, Boswell's ". . . legally consigning care and control to some other person," comes across like the process of adoption. Adoption is clearly different from infanticide. This part of Boswell's definition of infanticide may have been widespread in the Christian era of the Greaco-Roman world. It is highly probably that on one or two occasions a man or woman who abandoned a child secretly hoped that someone else may discover and rescue the child from cruel death.

\section{Child Euthanisia}

In the modern world, infanticide has taken a new shape and name. It is defined as child euthanasia. This is modernized infanticide. Proponents of child euthanasia give many reasons for killing a child in this manner. Euthanasia is defined by the Longman Dictionary of Contemporary English as "the deliberate killing of a person who is very ill and going to die, in order to stop them suffering." Child euthanasia which is a form of infanticide is gaining prominence in the medical 
world. Fletcher who is the Founder of Situational Ethics and a proponent of euthanasia suggests that in instances of severe birth defects, infanticide or child euthanasia should be carried out. He assumes that child euthanasia in these cases would be considered as humane, a reasonable and a conventional extension of abortion (Fletcher 1978). The Royal College of Obstetricians and Gynaecologists has advised that a debate on the issue of "non-resuscitation," in order words, decisions to withdraw treatment from the sickest of newborns, be encouraged. This is to ascertain whether it would be necessary to legalize child euthanasia, for if it is legalized, then mothers would be encouraged to continue their pregnancy to term, and would be willing to take any risk on an outcome, rather than opt for a late abortion (Templeton S. 2006). However, a senior pediatrician by the name Pieter Sauer who lives in the Netherlands suggests that since British neonatologists already carry out "mercy killings" secretly, they should be allowed to do so openly (Ibid).

How different is infanticide from child euthanasia? Practically, they are the same. While infanticide is carried out with careless abandon, without, highly probable, qualms of conscience, child euthanasia is done such that the parents or doctors or whoever had authority over the child's life believed the practice to be a display of mercy, and so invented the phrase; 'mercy killing.' How certain can anyone be by believing that he/she was showing mercy to a very sick, or very weak or severely deformed child by killing the child? The very fact that these very sick children had not given up the ghost, was a proof that they indeed wanted to live. Rather than perform his best to save the child's life, man throws in the towel and administers "mercy" death to these patients. What the proponents of child euthanasia seem to be conveying is that they understand the pain the weak child feels and they understand that the weak child indeed desires to die. They also 
seem to be suggesting that only the fittest needs to survive. Charles Darwin's 'survival-of-the-fittest theory does come to play here. Irrespective of how the proponents of child euthanasia intend that the world understands their philosophy, it does not negate the fact that they are prepared to administer death on a child who they believe is not fit enough to survive. This was the case in antiquity with regard to infanticide a very weak or sick child was exposed and abandoned to die because it was not fit enough to survive.

\section{Infanticide in the Roman Christian Era}

In spite of the fact that infanticide was supported by law (Duodecim Tabularum Leges (The Twelve Tables of the Law) (451-450 B.C,)) and some people were in support of it (M. Tulli Ciceronis De legibus, Lefkowitz Mary R., 1992), some other people kicked against it. This was the period when people's sensibilities against infanticide were influenced by the various philosophies and schools of thought that abound at this time. It was no other time than the Christian era. According to Price (2004), ancient Romans and Greeks were pagans therefore, practising infanticide was unproblematic, but the advent of Christianity brought to the fore the evils of infanticide. Some of the measures adopted by Christians in attempting to put an end to the practice of infanticide included; rescuing and adopting babies exposed, and strictly ensuring that their members did not partake of the practice. Price concludes that Christianity contributed greatly to the opposition of infanticide and its eventual prohibition. Here is witnessed a display of social responsibility and the selfish gene theory coming to play; an understanding that everyone deserves to live. 
Justin Martyr (100-165 A.D.) an early Christian Apologist and canonized a saint after his death, spoke and wrote against the practice of infanticide:

But as for us, we have been taught that to expose newly-born children is the part of wicked men; and this we have been taught lest we should do any one an injury, and lest we should sin against God, first, because we see that almost all so exposed (not only the girls, but also the males) are brought up to prostitution. . . . And there are some who prostitute even their own children and wives, and some are openly mutilated for the purpose of sodomy... (Justin Martyr, The First Apology)

During this era, many of the children who were exposed and abandoned, more often than not, were rescued for the purpose of being utilized, when they were old enough, to boost the income of the rescuer/s. Some were raised to become men and women of questionable characters. Sometimes, children were not rescued for the purpose of preserving their lives for the better, but to fulfill the lusts of the rescuers. Justin Martyr was not merely speaking against infanticide but prostitution which on a large scale, was birthed indirectly by infanticide.

Another author who condemned the practice was Tertullian, a Christian writer in A.D 200. He criticized the practice of infanticide, abortion and any other kind of child murder. He considered murder through drowning and through exposure and abandonment as very malicious. In the text below, he speaks firmly against the afore-mentioned practices and advises people to desist from such acts. 
But since in the case of infanticide it matters nothing whether it be committed under religious sanctions or out of mere caprice (although it does matter whether it is parental child-murder or manslaughter), I will appeal to the people. How many of those who stand around panting for the blood of the Christians,- - how many, think you, of yourselves even, magistrates most just and severe against us, shall I prick in their consciences, who are in the habit of strangling the children born to them? (Tertulian Apology 9:6, Transl. by Bindley T. and Herbert, M.A., 1890).

Lactantius, also a Christian writer, between the late third century and early fourth century A.D comments that parents strangle their own children, or expose them to their fate if they are too pious for such. Lactantius worrying about these infants affirms that, even if they are picked up by other people and survive, the probability that they would be brought up in brothels and slavery was high (Lactantius, Divine Institutes Book V.15). Here, Lactantius is corroborating Justin Martyr in condemning the practice of infanticide.

Philo Judaeus, a Jewish writer (20 A.D), was one of the authors who spoke against the practice. In his Special Laws, Philo speaks strongly against it, condemning peoples of other cultures for this infamous unjustified practice (Philo Judaeus, The Special Laws. III, XX.117, Volume VII ). He laments:

Some of them do the deed with their own hands; with monstrous cruelty and barbarity they stifle and throttle the first breath which the infants draw, or throw them into a river or into the depths of the sea, after attaching some heavy substance to make them sink more quickly 
under its weight. Others take them to be exposed in some desert place, hoping, they themselves say, that they may be saved, but leaving them in actual truth to suffer the most distressing fate. For all the beasts that feed on human flesh visit the spot and feast unhindered on the infants, a fine banquet provided by their sole guardians, those who above all others should keep them safe, their fathers and mothers (Philo Judaeus, The Special Laws III, XX, 114115).

He goes on to say that one may attempt to consider and justify the killing of an adult by bringing up so many excuses for the act of murder which is against the law but the killing of an infant child who is innocent of offences should not even be considered. He supports the Mosaic Law (the Law of Moses) which imposes the death penalty on anyone who carries out the practice of infanticide. It is probable that at this period parents may have among others mentioned above, committed the act for economic reasons. Having to feed more mouths than necessary may have been a challenge to many a parent. It must have been convenient to expose male and female children for this same objective. If it was for reasons of severe deformity, the children would not have been reared as prostitutes.

However, Tacitus (AD 124) wholeheartedly supports infanticide and speaks against people, especially the Jews who do not support it. In his Histories, he mentions some of the customs of the Jews such as circumcision, hatred for infanticide and frowning at any association with foreigners. He believes that these customs had the capacity to remain consistent because of the depravity of the Jews. Tacitus seems to be saying that the Jews had no moral justification to condemn infanticide, since they themselves carry out practices that are in themselves morally unjust. He states that the Jews 
hate foreigners and see their relationship with foreigners as abominable. Also, they sit apart at meals. Tacitus believes that they only term infanticide a crime because they intend to increase their population. In condemning the Jews, Tacitus affirms that they are hypocritical and partaking in activities they should not, rather than do what was right.

... the other customs of the Jews are base and abominable, and owe their persistence to their depravity. .. .the Jews are extremely loyal toward one another, and always ready to show compassion, but toward every other people they feel only hate and enmity. They sit apart at meals, and they sleep apart, and although as a race, they are prone to lust, they abstain from intercourse with foreign women; yet among themselves nothing is unlawful. They adopted circumcision to distinguish themselves from other peoples by this difference. Those who are converted to their ways follow the same practice, and the earliest lesson they receive is to despise the gods, to disown their country, and to regard their parents, children, and brothers as of little account. However, they take thought to increase their numbers; for they regard it as a crime to kill any late-born child (Tacitus, Histories 5.15).

From Tacitus, one is tempted to agree that the Jews condemned infanticide not necessarily because they viewed it as man's inhumanity to man, but because they yearned for increase in their population. And to Tacitus, infanticide may have been a method of controlling over-population. Therefore, a child who could not survive should quickly be done away with. 
After his conversion in about 320 A.D., Emperor Constantine the Great enacted two laws against child murder. The first law was to remove temptation to commit infanticide. To this end he provided funds out of the imperial treasury for parents who were over-burdened with children. The second law accorded all the rights of property of exposed infants to those who had the charity to save and nurture them (http://www.newadvent.org/cathen/08001b.htm). It is also highly probable that infanticide was done by the ancients as a means of preserving generations through time. A strong child was the progeny of a strong and healthy ancestor.

From Boswell's (1984) definition of abandonment, he is saying that exposition is not necessarily infanticide; it is more of putting out the child and hoping that the child would be picked up by strangers. If that happened, then the epositio should not be defined as infanticide, rather, it should be defined as an act that relinquished responsibility of the child from the parents to strangers. In the same vein, Harris (1994) makes a distinction between Exposer A and Exposer B, where the former was one who hoped for the rescue of the infant and the latter looked towards the death of the child. Either way, if the child in Exposer A is not rescued quickly, death would await the child. But, cruel death awaited the child in Exposer B. Prior to the Christian era, the child in case of either Exposer A or B, met with death. But in the Christian era, the child in Exposer A, was sometimes rescued.

The various reasons for infanticide in the pre- and Christian era of the Graeco-Roman world include: severe deformity, economic reasons, gender discrimination, survival of ancestry, population reduction, social deprivation and of course, survival-of-the-fittest.

Moran suggests that poverty was a major determinant to this awful practice. She also claims that in ancient Greece and Rome, parents who could not provide for their children 
disposed of them, principally during warring periods, famine and drought (Moran D.R. http://www.deathreference.com/Ho$\mathrm{Ka} /$ Infanticide.html). In the concluding chapter of his study carried out on infanticide, Milner (2000) asserts:

... with this strata of support, I have concluded that it is a normal - a natural - trait for a human being to be willing to kill his or her own child, especially during the first year of life, and that there are genetic factors which are determinative of this compulsion.

Is infanticide indeed "a normal - natural trait"? And is it justifiable to blame infanticide practice on genetic factors, or economic reasons? The truth of the matter is that children are very vulnerable because they are the weakest in society. They can neither fend for themselves nor are they able to defend themselves. Rather than being cared for, they became sacrificial victims on the altar of man's insufficiency and ineffectiveness in dealing with fundamental issues relating to personal and general freedom, well-being, success and progress of his mental and physical environment. Whether in antiquity or in modern times, infanticide presents a true picture of the strong taking advantage of the weak. It also presents a picture where it is the fittest that survives. Being fit and or fitter do not suffice. A child with severe deformities or a very sick child is more likely to be in this kind of a situation. It is pertinent to note here that in spite of this practice, parents loved new born babies and took care of them as it is observed in the satires of Persius (Persius, Satire 2.31-37), where the description is shown of the dotting grandmother who smears the baby with prophylactic spit.

However, Engels (1980) declares that infanticide was of "negligible importance" to the people. But facts from 
Classical authors make nonsense of Engels' calculations and conclusion. Other authors (Harris, 1980; Brunt, 1971 and Pomeroy, 1975) who disagree with Engels conclude that the extensive practice of infanticide in the Greaco-Roman world had considerable "demographic, economic and psychological" effect on society.

\section{Infanticide in Nigeria}

Infanticide practices occurred and continue to occur in Nigeria. The famous missionary to Nigeria, Mary Slessor rescued and saved the lives of twin babies from death in old Calabar, particularly the Efik community of Akpap Okoyong. Twin babies were believed to be evil therefore they were thrown into the river or abandoned to die in the bush. The arrival of this foreign missionary brought an end to the customary practice in that part of the country. However infanticide continues to be practised in Nigeria. Of particular interest is the one being blatantly done by some people in Abuja. They include, the Bassa komos, the Gbagy yamas, and the Ganaganas. The Gbajingala clan among the Bassa komos kills twins at birth. They believe that twins are strange spirits not fit to live among mortals. Therefore twin babies are taken forcefully from their mothers by masquerades that women are forbidden to see. Then the babies are poisoned or strangled. Thereafter, an altar is built by the walls of their huts where the spirits of the dead children are venerated. This people indeed believed that they were doing the twins, the parents and the society a great favour by doing away with the lives of twins because they thought twins to be evil and not fit to live among humans.

In this community also, a baby is tied to the corpse of its mother if the mother dies in childbirth. It is believed that this yet to be weaned baby killed the mother with its strange powers. In some of the other villages, the baby is sometimes abandoned on the grave of its mother, and at other times; the 
baby is left in the house without care. Consequently, the baby starves to death. Attempts are not made by villagers to save the baby; most importantly the villagers ensured that outsiders do not rescue such children.

Infanticide is also carried out for the simple reason that a baby grows the upper teeth first. Such a baby is considered bad omen. Many other reasons abound for the killing of babies. For the purpose of a bountiful harvest, young children are sacrificed to the god of fertility. Multiple births are aberration in the communities. Twins, triplets and quadruplets are either strangulated and buried in the bush or thrown into the Gurara River. For the Gbagy yamas, twin babies about to be killed are taken to the "ancestral home." Taking children to the "ancestral home" meant death, because the children never returned. These acts were done discretely so that attempts are not made by outsiders to rescue these condemned children. However Christian missionaries (Pastor Olushola Steve) are rescuing some of these children, albeit with difficulty, and providing a home for them. These acts are not different from child euthanasia. It is important to note at this juncture that the people who administer these deaths to the helpless children can be classified as the leaders of the people, the custodians of the laws of the community as well as the healers. The children were exterminated because they were not fit to coexist with other people. They were condemned to death because of man's desires to survive and his laziness to look beyond his spiritual beliefs and search for truth in the world of reality. If these children could defend themselves, they would not have been subjected to these acts of inhumanity. The strong often take advantage of the weak, in this case, children, in antiquity and in our modern world. 


\section{Conclusion}

This paper concludes with the argument that infanticide/ or child euthanasia in Abuja continued to be practiced due to lack of education and enlightenment among the people who observe it. Also, infanticide and child euthanasia in the Roman Christian era are one and the same. In antiquity, the people were not enlightened enough to understand that a baby born weak/ or premature could grow up strong and healthy if offered the appropriate opportunity. Irrespective of what proponents of child euthanasia say, administering death to a very sick person should be left to the Almighty God, that realm is His and His alone. It is not in the place of man to decide. They may argue that it is better to administer "mercy death" to a very sick child because the child would ultimately die. Should this be put into practice, it then suggests that many very sick children or severely deformed children may die prematurely. For it is a well known fact that some very sick children recover from their ailment, while some severely deformed children lived and impacted on their world positively. Even if they eventually die, they may have impacted on the mothers or caretakers positively. To the mothers or parents of these very sick children, every day, every hour and minute spent with these sick children brought hope to the parents; hope that the children may outlive the diseases plaguing them. And indeed there is nothing wrong in hope. Nicholas James "Nick" Vujicic, a Serbian Australian was born with a rare disorder called tetra-amelia. This disorder is characterized by the absence of all four limbs. His faith in God and his parents' love towards him kept him alive. Today he is an evangelist, a motivational speaker and a father. There are Nicholas Vujicics in every part of the world. They are leaving their footprints on the sands of time, in various sporting events as well as in the intellectual world. They were born with serious congenital deformities, but because they were offered 
opportunity to live, they have affected the world positively. Further studies could examine diverse religious inclinations toward infanticide/ or child euthanasia in the Graeco-Roman world and the modern world.

Monica Omoye Aneni is of the Department of Classics, University of Ibadan. 


\section{References}

Boswell John Eastburn, (1984). "Expositio and Oblatio: The Abandonment of Children and the Ancient and Medieval Family." American Historical Review 89, 12. Boswell, John, (1988). The Kindness of Strangers. NY: Vintage Books.

Brunt, P.A., (1971). Italian Manpower, 225 B.C.-A.D. 14. Oxford.

Christopher Price, (2004) Infanticide, retrieved from http://www.christiancadre.org/member_contrib/cp_infa nticide.html http://www.deathreference.com/HoKa/Infanticide.html.

Dianne R Moran,

Infanticide,

http://www.deathreference.com/Ho-

$\mathrm{Ka} /$ Infanticide.html.

Duodecim Tabularum Leges, (1909). in Fontes iuris Romani antiqui I, ed. Georg Bruns et Otto Gradenwitz Tübingen, Berlin.

Engels Donald, (1980). "The Problem of Female Infanticide in the Greaco-Roman World," Classical Philology 75.

Fletcher, Joseph, (1978). "Infanticide and the Ethics of Loving Concern," in Kohl, Marvin, Infanticide and the Value of Life, NY: Prometheus Books.

Harris V. William (1982). "The Theoretical Possibility of Extensive Infanticide in the Greaco-Roman World," Classical Quarterly 32, NO 1, 114-116. Cambridge University Press.

Niall Rudd , (1973). Horace: Satires and Epistles, Perseus: Satires, Persius, Satire 2.31-37. A verse translation and notes. Penguin Books, London.

Infanticide, (2008).The Columbia Encyclopaedia, Sixth Edition.

Justin Martyr, The First Apology Chapter XXVII, Guilt of Exposing Children, sourced from 
http://www.earlychristianwritings.com/text/justinmarty r-firstapology.html

Lactantius, Divine Institutes Book V.15., (2003).trans. Anthony Bowen and Peter Garnsey, Liverpool: Liverpool University Press.

Lefkowitz Mary R., (1992). Women's Life in Greece and Rome, A source book in translation; $2^{\text {nd }}$ Edition, The John Hopkins University Press, Baltimore.

Longman Dictionary of Contemporary English, (2005). Fourth edition with Writing Assistant, Longman Nigeria PLC.

M. Tulli Ciceronis, De legibus, Libri Tres. http://www.thelatinlibrary.com/cicero/leg.shtml Milner, Larry S. (1998). Hardness of Heart Hardness of Life: The Stain of Human Infanticide. Kearney, NE: Morris Publishing.

Pastor Olushola Steve is a Christian missionary and founder of The Vine Heritage Rescue and Fostering Home based in North Central Zone of Abuja rescues and provides a haven for exposed and abandoned children in that vicinity of Abuja

Philo Judaeus, The Special Laws III, XX, 114-115,( 1968).Translated by F. H. Colson, William Heinemann Ltd, London.

Pomeroy, S. B.., (1975). Goddesses, Whores, Wives, and Slaves, pp 140, 164-5, 228, New York.

Templeton, Sarah-Kate . "Doctors: let us kill disabled babies."

Sunday Times, (2006-11-05). Retrieved October, 2008.

Tertulian Apology 9:6, (1890).Translated by Bindley $\mathrm{T}$. Herbert, M.A., Merton College, Oxford. 